\title{
Modern Radiotherapy for Head and Neck Cancers: Benefits and Pitfalls - a Literature Review
}

\author{
Camil Ciprian MIRESTEAN ${ }^{1,5}$, Calin BUZEA², Roxana Irina IANCU3,4*, Dragos Teodor IANCU ${ }^{2,3}$
}

\begin{abstract}
Curative radiotherapy is part of the multimodal treatment for locally advanced head and neck cancers. The technical revolution in the field of radiation therapy and medical imaging has made possible a better conformation of the target volumes with irregular shapes with a dose reduction at the radiosensitive organs in the vicinity. Three-dimensional Conformal Radiotherapy (3D-CRT) has been replaced by Intensity Modulated Radiotherapy (IMRT), and more recently the Intensity Modulated Volumetric Arc Therapy (VMAT) technique is being used on an ever-expanding scale as a replacement for the "step and shot" IMRT technique. The benefits of the IMRT/VMAT techniques were mainly consisting of a better conformation for the target volumes with irregular shapes and the reduction of acute and late xerostomia. The results in the tumor control are considered similar to those obtained by the 3D-CRT technique except for nasopharyngeal cancer in which the use of chemo-radiotherapy by the IMRT technique has led to an improved local survival and local and regional control rate. Increasing the incidence of HPV-positive head and neck cancers with a better prognosis and the need to improve quality of life would be an argument in favor of using treatments with a low toxicity profile. By reducing the dose of healthy tissue, the use of modern irradiation techniques opens new horizons for the re-irradiation with high radiation doses of recurrent head and neck tumors.
\end{abstract}

Keywords: radiotherapy, 3D-CRT, IMRT, VMAT, OAR.

\section{Rezumat}

Radioterapia cu scop curativ face parte din tratamentul multimodal al cancerelor capului și gâtului local avansate. Evoluția tehnicilor de iradiere a făcut posibilă o mai bună conformare a volumelor țintă având forme neregulate cu o reducere a dozelor la organele radiosensibile din proximitate. Radioterapia conformațională tridimensională (3DCRT) a fost înlocuită cu radioterapia cu intensitate modulată (IMRT), iar mai recent tehnica Arc Terapie Volumetrică cu Intensitate Modulată (VMAT) este utilizată la scară din ce în ce mai largă ca înlocuitor al tehnicii IMRT „step and shot". Beneficiile tehnicii IMRT/VMAT au fost constituite în principal de o mai bună conformare a volumelor țintă cu formă neregulate și de reducerea xerostomie. Rezultatele în controlul tumoral sunt considerate similar cu cele obținute prin tehnica 3D-CRT cu excepția cancerului de rinofaringe în care utilizarea chimio-radioterapiei prin tehnica IMRT a condus la o rată de control local și supraviețuire îmbunătățită. Creșterea incidenței cancerelor de cap și gât HPV-pozitive cu prognostic mai bun și necesitatea îmbunătățirii calității vieții ar fı un argument în favoarea utilizării unor tratamente cu un profil de toxicitate redus. Prin reducerea dozelor primite de testul sănătos, utilizarea tehnicilor moderne de iradiere deschide noi orizonturi pentru re-iradierea cancerelor capului și gâtului recidivate.

Cuvinte cheie: radioterapie, cap, gât, IMRT, VMAT, multimodal, toxicitate, HPV.

\footnotetext{
${ }^{1}$ University of Medicine and Pharmacy, Craiova, Romania

${ }^{2}$ Regional Institute of Oncology, Iasi, Romania

${ }^{3}$ "Gr. T. Popa" University of Medicine and Pharmacy, lasi, Romania

${ }^{4}$ "Sf. Spiridon" University Hospital, lasi, Romania

${ }^{5}$ EUROCLINIC Oncological Center, lasi, Romania
}

\section{Corresponding author.}

Roxana Irina lancu, Department of Pathophysiology,

„Gr. T. Popa" University of Medicine and Pharmacy, 16 University Street, 700115 , lasi, Romania.

E-mail: rox_iancu@yahoo.com, riiancu@umfi asi.ro 


\section{INTRODUCTION}

Curative radiotherapy is part of the multimodal treatment of locally advanced squamous cell carcinoma of the head and neck (HNSCC) as a unique method of treatment or in combination with concurrent or sequential chemotherapy. The lasts decades have come with changes and a significant progress in improving irradiation techniques and with the implementation of multidisciplinary treatments by combining induction or concurrent chemotherapy or Cetuximab based biological therapy. The goal of quality based radiotherapy is to improve the therapeutic ratio that establishes the efficacy/toxicity ratio. IMRT technique has become a standard in the treatment of HNSCC following Phase III Intensity Modulated Radiation Therapy (IMRT) versus conventional radiotherapy in head and neck cancer (PARSPORT trial). The purpose of this study was to demonstrate the advantage of the IMRT technique in the proportion of patients presenting xerostomia 2 or higher degree, 1 year after the completion of the treatment for head and neck cancers. The control group received radiotherapy by $3 \mathrm{D}$-Conformal technique (3D-CRT) ${ }^{1}$.

Xerostomia associated with dry mouth syndrome is one of the complications that most severely affect the quality of life for radiotherapy and radio-chemotherapy treated patients for the head and neck cancers. The irradiation of the salivary glands region leads to changes in the glands volume, consistency and $\mathrm{pH}$ and composition of the secreted saliva. These phenomena are also implicated in the pathogenesis of the tooth diseases that affect structure and resistance. Xerostomia is also related to infections of the oral cavity.

\section{Intensity Modulated Radiation Therapy (IMRT) in HNSCC}

Reducing the volume of parotid glands receiving a high dose of radiation has been shown to be a necessary condition for reducing severe xerostomia, but irradiation of level II lymph nodes makes it difficult by standard radiotherapy technique to spare parotid glands. Limiting doses to at least one parotid gland or if it is not possible to reduce the dose received by a sub-volume from the parotid glands is a purpose for reducing post-irradiation xerostomia. The severity of salivary gland damage depends on the total radiation dose and irradiated volume, recent studies being focused on the possibility of parotid glands sparing. Evaluation of salivary flow or salivary gland scintigraphy as well as subjective eva- luation of patients „reports of dry mouth syndrome” demonstrated the ability of the IMRT technique to protect the parotid glands compared to the 3D-CRT irradiation technique. However, avoiding the parotid glands to reduce xerostomia should be approached with caution in order not to affect the tumor target volume dosimetric coverage. Eisburuch et al. notes that an improvement in saliva production over time associated with dose reduction in the parotid glands may lead to a reduction in late xerostomia. The authors identify the average dose of the oral cavity as an independent predictor of xerostomia, stressing the need to reduce the doses received by the tumor-free oral cavity ${ }^{2}$.

However, the IMRT technique also has disadvantages, requiring quality assurance of the treatment plan by verifying it in the phantom or with the help of portal dosimetry and the large number of fascicles can increase the irradiation time with possible radiobiological consequences if the treatment time per fraction exceed 20 minutes. The large number of monitor units (MU) associated with the scattering of small doses into large volumes of tissue ${ }^{3}$.

Dysphagia associated with irradiation in patients receiving radiotherapy for $\mathrm{HNSCC}$ was defined as aspiration or stricture evidenced by video-fluoroscopy or endoscopy, gastrostomy tube or aspiration pneumonia diagnosed at $\geq 12$ months after treatment completion. Evaluation of this toxicity associated with IMRT treatment for multimodal patients treated for oropharyngeal cancer revealed an age-dependent incidence increasing from $5 \%$ to $20 \%$ for patients $<50$ years of age $>70$ years receiving a dose $>60 \mathrm{~Gy}$ per pharyngeal constrictor superior evaluated on volume dose histograms $(\mathrm{DVH})^{4}$.

A systemic review analyzed the benefit in terms of xerostomia, overall survival (OS) and quality of life (QOL) included patients from randomized controlled trials diagnosed with locally advanced, non-metastatic HNSCC who received radiotherapy with curative intent. The analysis included 1155 patients, s treated with conventional IMRT and 2D or 3D-CRT radiotherapy in HNSCC. The use of the IMRT technique has led to a relative reduction in the risk of $36 \%$ acute grade 2 xerostomia and the risk of late xerostomia compared to the $2 \mathrm{D}$ and 3D-CRT techniques. Benefit in local control and OS for IMRT technique was found only in nasopharyngeal cancers. The authors reports that no solid conclusions can be formulated regarding the ability of IMRT to reduce xerostomia, but there is evidence in favor of reducing this acute and late salivary toxicity of degree $>2^{5}$. 


\section{Intensity Modulated Volumetric Therapy (VMAT) in HNSCC}

Volumetric Intensity Modulated Arc Therapy (VMAT) is a newer radiotherapy technique than "step and shot" IMRT, based on the treatment is delivered while gantry of Linac performs a continuous rotation simultaneously with the modulation of the beam intensity using the multi-leaf collimator (MLC). The advantage of the technique is the increase in conformity of the treatment plan and the treatment dose delivery in a shorter time compared with the IMRT technique. Also some studies highlight the possibility of reducing the monitor units (MU) number and a better dose homogeneity compared to the plans obtained by the IMRT technique ${ }^{3,5}$.

Verbakel et al. evaluated the potential advantages of VMAT technique over IMRT by comparing treatment plans for nasopharynx, oropharynx and hypopharynx cancers. Treatment plans based on 2 complete arcs used were superior in terms of dose delivery time and dose homogeneity, and in terms of organ at risk sparing (OAR), VMAT plans were similar to the plans IMRT' ${ }^{6}$.

A study that included 222 patients diagnosed with oropharyngeal cancers (134 who received radiation therapy using the IMRT technique and 88 who were irradiated by the VMAT technique) analyzed dysphagia and xerostomia of degree 2 or greater. All the treatment plans were dosimetric compared. In the group of patients irradiated by VMAT technique, the toxicities were significantly lower ${ }^{7}$.

The same superiority for VMAT technique in reducing the number of MU to $30 \%$ compared with IMRT radiotherapy is also demonstrated by a retrospective study by Fung-Kee-Fung and collaborators for concurrent radio-chemotherapy treated patients for head and neck cancer (stages II-IV) ${ }^{8}$.

Although the irradiation techniques have improved considerably, xerostomia remains a difficult problem to solve even in the era of modern techniques, the rate of xerostomia remaining high even when using new techniques. By retrospectively analyzing data from the dosimetry of 609 patients, the average dose and the average percentage of the volume of the salivary gland that received at least 26Gy (V26) evaluated for the contralateral parotid gland were $24.50 \mathrm{~Gy}$ and $40.92 \%$ . Identifying an average dose of $48.18 \mathrm{~Gy}$ for submandibular glands, the study authors conclude that even if the submandibular glands are not sufficiently considered as OAR, the "level one" priority should be to target volume coverage target and the OAR protection associated with xerostomia remain only a ,second level priority"

Late xerostomia may ocur at large intervals after IMRT irradiation with a decreasing tendency over time. Although the toxicities at large intervals after treatment are rare, Baudelet et al. reported an increase in the risk of dysphagia between 5 and 8 years after treatment, observing a non-linearity of the phenomenon, both for dysphagia and for fibrosis of the neck ${ }^{10}$.

Radiation superiority of IMRT technique in nasopharyngeal cancer has been demonstrated by a metaanalysis including 8 studies and 3570 patients, (1541 treated by IMRT technique and 2029 treated by 2D and 3D-CRT techniques). The authors compared the clinical results of the treatment regression free survival (PFS) and OS in both patients groups and the late toxicities of intensity modulated radiotherapy (IMRT) with those obtained with two-dimensional radiotherapy (2D-RT) or three-dimensional conformal radiotherapy (3D-CRT) in nasopharyngeal carcinoma. IMRT technique has shown superiority in OS but also in tumor control. There was also a lower rate of trismus and temporal lobe neuropathy in the IMRT radiotherapy treated patients ${ }^{11}$.

\section{CONCLUSIONS}

The IMRT technique has become a therapeutic standard in curative treatment, proving the ability to reduce acute and late toxicity and superiority in survival and loco-regional control in nasopharyngeal cancer. The VMAT technique offers a reduction of the irradiation time, avoiding the negative radiobiological consequences of the prolonged dose delivery time, and increasing the patient's comfort level and limiting the risk of ballistic errors in dose delivery by reducing the immobilization time. Combining the dosimetric qualities of the IMRT «step and shot» plan with the advantages in reducing the delivery time of the VMAT treatment could replace the IMRT method in the treatment of HNSCC.

Compliance with ethics requirements: The authors declare no conflict of interest regarding this article. The authors declare that all the procedures and experiments of this study respect the ethical standards in the Helsinki Declaration of 1975, as revised in 2008(5), as well as the national law. Informed consent was obtained from all the patients included in the study. 


\section{References}

1. Nutting $C$, Harrington $K$, Rogers S, Sydenham M, A'Hern R, Hall E. Results of a Phase III Multi-centre Randomised Controlled Trial of Intensity Modulated (IMRT) vs Conventional Radiotherapy (RT) in Head and Neck Cancer (PARSPORT: ISRCTN48243537; CRUK/03/005). Clin. Oncol. 2010;22(10):899

2. X. Wang and A. Eisbruch, IMRT for head and neck cancer: reducing xerostomia and dysphagia. Asian Pac J Cancer Prev. 2018; 19(1): 207-211.

3. Verbakel WF, Cuijpers JP, Hoffmans D, Bieker M, Slotman BJ, Senan S. Volumetric intensity-modulated arc therapy vs. conventional IMRT in head-and-neck cancer: a comparative planning and dosimetric study. Int J Radiat Oncol Biol Phys. 2009 May 1;74(1):252-9.

4. MD Anderson Head and Neck Cancer Symptom Working Group; Spatial-Non-spatial Multi-Dimensional Analysis of Radiotherapy Treatment/Toxicity Team (SMART3). Chronic radiation-associated dysphagia in oropharyngeal cancer survivors: Towards age-adjusted dose constraints for deglutitive muscles. Clin Transl Radiat Oncol. 2019 Jun 15;18:16-22.

5. Gupta T, Kannan S, Ghosh-Laskar S, Agarwal JP. Systematic review and meta-analyses of intensity-modulated radiation therapy versus conventional two-dimensional and/or or three-dimensional radiotherapy in curative-intent management of head and neck squamous cell carcinoma. PLoS One. 2018 Jul 6;13(7)

6. Verbakel WF, Cuijpers JP, Hoffmans D, Bieker M, Slotman BJ, Senan S. Volumetric intensity-modulated arc therapy vs. conventional IMRT in head-and-neck cancer: a comparative plan- ning and dosimetric study. Int J Radiat Oncol Biol Phys. 2009 May 1;74(1):252-9.

7. Cui T, Ward MC, Joshi NP, Woody NM, Murray EJ, Potter J, Dorfmeyer AA, Greskovich JF Jr, Koyfman SA1, Xia P. Correlation between plan quality improvements and reduced acute dysphagia and xerostomia in the definitive treatment of oropharyngeal squamous cell carcinoma. Head Neck. 2019 Apr;41(4):1096-1103. doi: 10.1002/hed.25594. Epub 2019 Jan 31.

8. Fung-Kee-Fung SD, Hackett R, Hales L, Warren G, Singh AK. A prospective trial of volumetric intensity-modulated arc therapy vs conventional intensity modulated radiation therapy in advanced head and neck cancer. World J Clin Oncol. 2012 Apr 10;3(4):57-62.

9. Vallard A, Guy JB, Mengue Ndong S, Vial N, Rivoirard R, Auberdiac P, Méry B, Langrand-Escure J, Espenel S, Moncharmont C, Ben Mrad M, Diao P, Goyet D, Magné N Intensity-modulated radiotherapy or volumetric-modulated arc therapy in patients with head and neck cancer: Focus on salivary glands dosimetry. Head Neck. 2016 Jul;38(7):1028-34.

10. Baudelet $M$, Van den Steen L, Tomassen P, Bonte K, Deron P, Huvenne W, Rottey S, De Neve W, Sundahl N, Van Nuffelen G, Duprez F. Very late xerostomia, dysphagia, and neck fibrosis after head and neck radiotherapy. Head Neck. 2019 Jul 22.

11. Zhang B, Mo Z, Du W, Wang Y, Liu L, Wei Y. Intensity-modulated radiation therapy versus $2 \mathrm{D}-\mathrm{RT}$ or $3 \mathrm{D}-\mathrm{CRT}$ for the treatment of nasopharyngeal carcinoma: A systematic review and metaanalysis. Oral Oncol. 2015 Nov;51(11):1041-1046. 